\title{
Hemochromatosis type 3
}

INSERM

\section{Source}

INSERM. (1999). Orphanet: an online rare disease and orphan drug data base.

Hemochromatosis type 3. ORPHA:225123

Type 3 hemochromatosis is a form of rare hereditary hemochromatosis $(\mathrm{HH})($ see this term), a group of diseases characterized by excessive tissue iron deposition of genetic origin. 